\title{
Pengaruh ukuran partikel arang dari limbah tutup botol plastik terhadap kualitas briket
}

\section{Effect of charcoal particle size from plastic bottle caps waste on briquette quality}

\author{
Erlinda Ningsih*, Kartika Udyani, Agus Budianto, Nur Hamidah, Siti Afifa \\ Institut Teknologi Adhi Tama Surabaya, Jl. Arief Rahman Hakim No. 100 Surabaya 60117, Indonesia \\ *Penulis korespondensi. Tel. +62 5230667066 \\ E-mail: erlindaningsih84@itats.ac.id; raiya1904@gmail.com
}

\begin{abstract}
The amount of plastic waste increases with the increase in plastic use, especially in the food industry. Plastic waste is waste that is very difficult to decompose and takes a long time to spoil. Plastic bottle caps are a type of polypropylene (PP) plastic which is recommended to be used only once. The research objective was to determine the effect of particle size on the briquette characteristics of plastic bottles based on the proximate analysis. The proximate analysis carried out was moisture content, ash content, volatile matter, fixed carbon, and calorific value. The research design used was a burning temperature of $450^{\circ} \mathrm{C}$, a burning time of 60 minutes, and particle sizes of 40, 60, and 100 mesh. The results showed that the particle size of 40 mesh had the best characteristics, namely water content of $0.5 \pm 0,05 \%$, ash content of $2 \pm 0,25 \%$, volatile matter content of $15 \pm 0,51 \%$, bound carbon content of $82.5 \pm 0,32 \%$, and a heating value of $9,982.779 \pm 240,017 \mathrm{cal} / \mathrm{gram}$. Based on the results of the proximate analysis, it can be concluded that a particle size of 40 mesh can improve the quality of briquettes compared to 100 mesh.
\end{abstract}

Keywords: bottle cap waste, briquette, particle size, PP plastic, proximate analysis.

\section{ABSTRAK}

Jumlah limbah plastik bertambah seiring peningkatan penggunaan plastik khususnya pada industri makanan. Limbah plastik merupakan limbah yang sangat sulit diurai dan membutuhkan waktu yang lama untuk terurai. Tutup botol plastik tergolong jenis plastik PP yang penggunaannya disarankan hanya sekali pakai. Tujuan penelitian adalah untuk mengetahui pengaruh ukuran partikel terhadap karakteristik briket dari botol plastik berdasarkan analisis proksimat. Analisis proksimat yang dilakukan adalah kadar air, kadar abu, kadar zat menguap, kadar karbon terikat, dan nilai kalor. Rancangan penelitian yang digunakan yaitu suhu pembakaran $450{ }^{\circ} \mathrm{C}$, waktu pembakaran 60 menit, dan ukuran partikel 40, 60, dan 100 mesh. Hasil penelitian menunjukkan bahwa pada ukuran partikel 40 mesh memiliki karakteristik terbaik yaitu kadar air $0,5 \pm 0,05 \%$, kadar abu $2 \pm 0,25 \%$, kadar zat menguap $15 \pm 0,51 \%$, kadar karbon terikat $82,5 \pm 0,32 \%$, dan nilai kalor sebesar 9.982,779 $\pm 240,017 \mathrm{kal} /$ gram. Berdasarkan hasil analisis proksimat dapat disimpulkan bahwa ukuran partikel 40 mesh dapat meningkatkan kualitas briket dibandingkan 100 mesh.

Kata kunci: analisis proksimat, briket, limbah tutup botol, plastik PP, ukuran partikel.

\section{PENDAHULUAN}

Industri makanan merupakan industri terbesar yang banyak memanfaatkan plastik sebagai pembungkus makanan. Plastik menjadi salah satu alternatif untuk pembungkus makanan karena murah, praktis, dan efisien. Hal ini memicu meningkatnya jumlah limbah plastik dan permasalahan lingkungan semakin memburuk (Siddiqui \& Redhwi, 2009). Sehingga perlu dilakukan sebuah solusi untuk mengurai dan 
mengolah plastik menjadi bahan yang dapat dimanfaatkan lagi. Umumnya daur ulang yang dilakukan adalah mengolah limbah plastik menjadi hasta karya seperti kerajinan tangan dan baju (Septhiani \& Septiani, 2015). Plastik yang banyak digunakan di pasar domestik adalah Polypropylene (PP), Polyethylene (PE), Polystyrene (PS), Polyvinyl Chloride (PVC), Acrylonitrile Butadiene Styrene (ABS), dan Polyethylene Terephtalate (PET). Sedangkan limbah plastik yang paling banyak ditemui di sampah perkotaan adalah jenis PP dan HDPE (Sahwan et al., 2005). Laju peningkatan volume limbah plastik ini akan terus meningkat seiring dengan bertambahnya jumlah penduduk dan pemakaiannya yang diperkirakan mengalami kenaikan sebesar 5\% dengan pertumbuhan penduduk 1,6\% untuk daerah Surabaya (Hapsari \& Herumurti, 2017).

Salah satu pemanfaatan limbah plastik yang telah dilakukan oleh beberapa peneliti adalah limbah plastik menjadi bahan tambahan pembuatan briket, hasil yang didapat adalah penambahan plastik pada briket yang terbuat dari sampah organik atau limbah pertanian dapat meningkatkan nilai kalor. Pengaplikasian plastik menjadi briket bertujuan untuk pemenuhan energi yang mulai langka. Plastik yang digunakan adalah jenis HDPE karena memiliki nilai kalor yang tinggi yaitu sebesar $11,047 \mathrm{kkal} / \mathrm{kg}$. Asip et al. (2014) telah melihat pengaruh komposisi persentase massa antara LDPE, serbuk arang tempurung kelapa:serbuk arang cangkang sawit dan suhu karbonasi, hasil yang didapatkan pada komposisi 10\% massa limbah plastik LDPE, 50\% massa cangkang sawit temperatur karbonisasi 500 ${ }^{\circ} \mathrm{C}$, dan $40 \%$ massa tempurung kelapa dengan nilai kalor $7.508 \mathrm{kal} / \mathrm{g}$, kadar air 4,30\%, kadar zat menguap $26,78 \%$, dan kadar karbon terikat 64,97\%.

Penelitian Bhoumick et al. (2016) menghasilkan kesimpulan bahwa kualitas briket meningkat dengan proporsi optimal dari limbah plastik yang ditambahkan dengan biomassa. Pada penambahan $10 \%$ plastik menghasilkan properti terbaik dan merekomendasikan untuk membuat briket dengan mengkombinasikan plastik dan biomassa. Hal yang sama dilakukan oleh Riyadi et al. (2016), yang menunjukkan bahwa penambahan plastik yang optimum yaitu $20 \%$ bagas dan $80 \%$ plastik menghasilkan nilai kalor tertinggi yaitu $9.055 \mathrm{kkal} / \mathrm{kg}$. Sedangkan Suwinarti et al. (2018), mengkombinasikan limbah biomassa dengan minyak jelantah dan plastik dan menyimpulkan nilai kalor tertinggi briket yang baik dengan adanya penambahan plastik $30 \%$ yaitu sebesar 33,56 $\mathrm{MJ} / \mathrm{kg}$. Hamzah (2019) melakukan penelitian pembuatan briket dari plastik dan menyimpulkan bahwa plastik dapat dijadikan bahan alternatif dan memiliki kalor yang tinggi. Penguraian ikatan pada polimer pada proses pengarangan tanpa oksigen merupakan salah satu teknologi yang tepat untuk konversi energi dari plastik (Gao, 2010; Tuffi et al., 2018).

Berdasarkan studi literasi yang sudah dilakukan, maka perlu dilakukan upaya untuk memanfaatkan limbah plastik dan peningkatan kualitas briket. Pemanfaatan plastik PP menjadi bahan briket karena komposisi limbahnya cukup tinggi. Mengingat penggunaan PP sebagai tutup botol sangat banyak dan belum ada penelitian penggunaan limbah PP untuk briket. PP yang digunakan pada penelitian ini adalah tutup botol dengan variasi ukuran partikel arangnya. Diharapkan dari penelitian ini menghasilkan briket dengan kualitas terbaik dan mengurangi limbah plastik.

\section{BAHAN DAN METODE \\ Bahan Penelitian}

Bahan utama penelitian ini adalah tutup botol plastik khususnya dari tutup minuman kesehatan home industri (infused water), pada tutup botol tersebut tercantum kode plastik yaitu 5, angka ini menunjukkan jenis plastik PP. Bahan perekat yang digunakan adalah tepung tapioka, yang didapatkan dari sebuah produk pasaran. Bahan perekat ini dibuat dengan perbandingan 2:5 antara tepung tapioka dan aquades.

\section{Peralatan Penelitian}

Peralatan utama yang digunakan dalam penelitian ini adalah furnace model mini dengan ukuran chamber $100 \times 100 \times 100 \mathrm{~mm} ; 1000 \mathrm{~W}$; $220 \mathrm{VAC} / 50 \mathrm{~Hz}$ suhu maksimum $1200{ }^{\circ} \mathrm{C}$, yang digunakan untuk proses pengarangan tutup botol plastik, blender dan alat pengepres yang digunakan untuk mencetak briket merupakan alat cetak briket manual rangka kokoh dengan material terbuat dari besi UNP (U-channel). Hasil ukuran cetakannya $2 \times 3 \mathrm{~cm}$. Gambar alat disajikan pada Gambar 1 .

\section{Metode Penelitian}

Tahapan awal penelitian ini adalah mencuci 
tutup botol plastik air mineral yang akan diproses. Tutup botol yang sudah bersih dikeringkan dan dilakukan pemotongan untuk mempermudah proses pengarangan. Proses pengarangan dilakukan pada suhu $450{ }^{\circ} \mathrm{C}$ dengan lama waktu pengarangan 60 menit menggunakan furnace. Arang tutup botol yang dihasilkan dikecilkan ukuran partikelnya menjadi 40, 60, dan 100 mesh menggunakan blender selama 15 menit. Arang yang sudah dikecilkan berdasarkan variabel ukuran kemudian diayak agar ukuran partikelnya seragam. Arang yang berukuran sesuai ukuran akan lolos ayakan, sedangkan yang tidak lolos akan tertinggal di ayakan. Arang yang tidak lolos akan dikecilkan berdasarkan variabel ukuran. Setelah ukuran partikel arang tutup botol seragam, bahan tersebut dicampur dengan perekat tepung tapioka yang sudah diencerkan, dengan perbandingan 1:5. Tahapan akhir dari proses pembuatan briket ini adalah pencetakan dengan alat pengepres. Briket yang dihasilkan dianalisa meliputi kadar air (ASTM D-3173), kadar abu (ASTM D-3174), kadar zat menguap (ASTM D- 3175), kadar karbon terikat (ASTM D.3172-07), dan nilai kalor (ASTM D.5865-10a).

\section{Kadar air}

Sampel yang akan dianalisa ditimbang sebanyak \pm 1 gram. Sampel selanjutnya dikeringkan di dalam oven pada suhu $105{ }^{\circ} \mathrm{C}$ hingga massa konstan. Sampel didinginkan dalam desikator. Kadar air dihitung dengan persamaan (1).

Kadar Air $(\%)=\frac{\mathrm{w}_{\mathrm{o}}-\mathrm{W}}{\mathrm{W}_{\text {so }}} \times 100 \%$

dengan,

$\mathrm{W}_{\mathrm{O}} \quad=$ massa sampel dan cawan sebelum dikeringkan $(\mathrm{g})$

$\mathrm{W}=$ massa sampel dan cawan sesudah dikeringkan (g)

$\mathrm{W}_{\text {so }} \quad=$ massa sampel awal (g)

\section{Kadar abu}

Sampel ditimbang sebanyak 1 gram. Kemudian sampel dimasukkan ke dalam furnace pada suhu $600-800{ }^{\circ} \mathrm{C}$ selama 4 jam sehingga semua karbon hilang. Sampel didinginkan di dalam desikator kemudian ditimbang untuk mendapatkan berat abu. Persamaan (2) digunakan untuk menghitung kadar abu.
$\operatorname{Kadar} \operatorname{Abu}(\%)=\frac{\mathrm{w}_{\mathrm{o}}}{\mathrm{W}_{\mathrm{dso}}} \times 100 \%$

dengan,

$\mathrm{W}_{\mathrm{O}}=$ massa sampel setelah pengabuan $(\mathrm{g})$

$\mathrm{W}_{\mathrm{dso}}=$ massa sampel sebelum pengabuan $(\mathrm{g})$

\section{Kadar zat menguap}

Sampel ditimbang sebanyak 1 gram. Sampel dipanaskan pada furnace dengan suhu $750{ }^{\circ} \mathrm{C}$ selama 7 menit. Kemudian didinginkan dalam desikator. Kadar abu (\%) dihitung dengan persaman (3).

Kadar zat menguap $(\%)=\frac{\mathrm{W}_{0}-\mathrm{W}}{\mathrm{W}_{\mathrm{n}}} \times 100 \%$

dengan,

$\mathrm{W}_{\mathrm{o}}=$ massa sampel awal $(\mathrm{g})$

$\mathrm{W}=$ massa sampel akhir $(\mathrm{g})$

\section{Kadar karbon terikat}

Kadar karbon terikat diperoleh jika kadar air, abu, dan kadar zat menguap sudah diketahui. Persamaan (4) digunakan dalam penghitungan kadar karbon terikat.

$F C=100 \%-(K A+Z T+X)$

dimana,

$\mathrm{FC} \quad=$ kadar karbon terikat (\%)

$\mathrm{KA}=$ kadar air $(\%)$

$\mathrm{ZT}=$ kadar zat menguap (\%)

$\mathrm{X} \quad=$ kadar abu (\%)

\section{Nilai kalor}

Pengujian nilai kalor bruto menggunakan alat bomb calorimeter dan perhitungan dengan nersamaan (5)

$Q_{\text {vad }}=\frac{\left[\left(t E_{e}\right)-e 1-e 2-e 3-e 4\right]}{C}$

dimana,

$\mathrm{Q}_{\text {vad }} \quad=$ nilai kalori $(\mathrm{J} / \mathrm{g})$

$\mathrm{E}_{\mathrm{e}} \quad=$ kalor pada alat bom $\left(\mathrm{J} /{ }^{\circ} \mathrm{C}\right)$

$\mathrm{T} \quad=$ suhu saat dinaikkan $\left( \pm 10,7^{\circ} \mathrm{C}\right)$

e1 = nilai asam $(\mathrm{J})$

e2 = nilai campuran saat proses bom $(\mathrm{J})$

e3 = nilai belerang $(\mathrm{J})$

e4 = nilai proses pembakaran bantuan $(\mathrm{J})$

$\mathrm{C} \quad=$ massa sampel $(\mathrm{g})$

Parameter yang diujikan merupakan tolak 
ukur kualitas briket kemudian dibandingkan dengan Standar Nasional Indonesia SNI Briket Arang 01-6235-2000. Penelitian ini membahas pengaruh ukuran partikel arang plastik terhadap analisa proksimat sebagai tolak ukur kualitas briket yang dihasilkan dibandingkan dengan SNI Briket Arang 01-6235-2000.

\section{HASIL DAN PEMBAHASAN}

Diversifikasi produk pemanfaatan plastik untuk briket merupakan salah satu alternatif mengoptimalkan pemanfaatan limbah plastik (Purwanto \& Sofyan, 2014). Pirolisis merupakan salah satu teknologi yang tepat untuk pemulihan energi dari limbah plastik (Sarker et al., 2011). Proses pirolisis plastik jenis PP akan terurai menjadi karbon berlangsung pada suhu $450{ }^{\circ} \mathrm{C}$ tanpa adanya oksigen (Gao, 2010; Pek \& Ghosh, 2015). Salah satu faktor untuk meningkatkan nilai tiap parameter dalam analisis proksimat secara signifikan adalah ukuran partikel arang (Purwanto \& Sofyan, 2014). Briket arang tutup botol diuji kadar air, kadar abu, kadar zat menguap, kadar karbon terikat, dan nilai kalor untuk melihat pengaruh ukuran partikel arang sebagai indikator kualitas briket. Hasil pengujian analisis proksimat dibandingkan dengan SNI briket 01-6235-2000. Berikut hasil cetak briket yang dihasilkan pada Gambar 2.

\section{Kadar Air}

Kadar air merupakan salah satu parameter penentu kualitas briket karena berpengaruh terhadap kemudahan pembakaran, daya pembakaran, nilai kalor, dan asap yang dihasilkan selama pembakaran (Iskandar et al., 2019). Pada Gambar 3 terlihat bahwa kadar air semua sampel pada briket tutup botol sudah memenuhi standar SNI yaitu $\leq 8 \pm 0,8 \%$. Plastik dapat meningkatkan daya rekat dan kekompakan tekstur, sehingga dapat meningkatkan nilai kerapatan dan kadar air yang lebih rendah (Suwinarti et al., 2018).

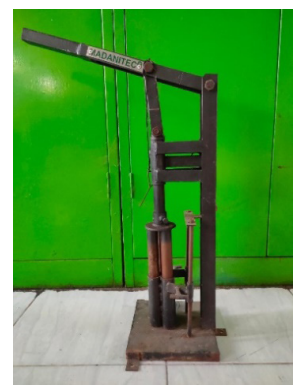

Gambar 2. Briket arang tutup botol.
Fenomena pengaruh ukuran partikel arang terhadap kadar air seharusnya berbanding terbalik yaitu semakin besar ukuran partikel maka kadar air semakin menurun (Faruq, 2019). Sedangkan kadar air yang didapatkan sama dengan penelitian Naryono et al. (2019) yaitu memiliki hubungan berbanding lurus, hal ini disebabkan oleh ukuran partikel yang besar lebih sedikit menyerap air (Prayitno et al., 2018). Ukuran partikel yang besar mempunyai luas permukaan yang kecil sehingga kemampuan daya serapnya pun kecil. Kadar air terendah didapatkan pada sampel ukuran partikel 40 mesh, yaitu $0,5 \pm 0,05 \%$ dan yang tertinggi pada sampel ukuran 80 mesh, yaitu $2 \pm 0,25 \%$.

\section{Kadar Abu}

Kadar abu yang terbaik dihasilkan berdasarkan Gambar 4 didapatkan $2 \pm 0,25 \%$ pada ukuran partikel 40 mesh. Sedangkan kadar abu tertinggi $6,9 \pm 0,48 \%$ pada ukuran partikel 80 mesh. Hasil semua analisa kadar abu masih memenuhi standar SNI yaitu $\leq 8 \%$. Senyawa anorganik yang terkandung dalam bahan baku briket dapat mempengaruhi kadar abu dalam briket pada saat proses pengarangan (Septhiani \& Septiani, 2015; Yuliza et al., 2013). Kadar abu yang tinggi menyebabkan nilai transfer panasnya rendah dan menimbulkan emisi debu yang tinggi (Karim et al., 2014). Ukuran partikel arang juga berpengaruh terhadap kadar abu briket, semakin besar ukuran partikel menjadikan ikatannya longgar sehingga memungkinkan jumlah oksigen yang mengalir cukup dan menyebabkan terjadi pembakaran sempurna. Hal ini dijelaskan oleh Bhattarai et al. (2016) dan hasil yang diperoleh menunjukkan fenomena yang sama.

\section{Kadar Zat Menguap}

Gambar 5 menunjukkan bahwa kadar zar menguap mengalami penurunan dengan memperkecil ukuran partikel. Hasil yang didapat kadar zat menguap terendah sebesar $11 \pm 0,26 \%$

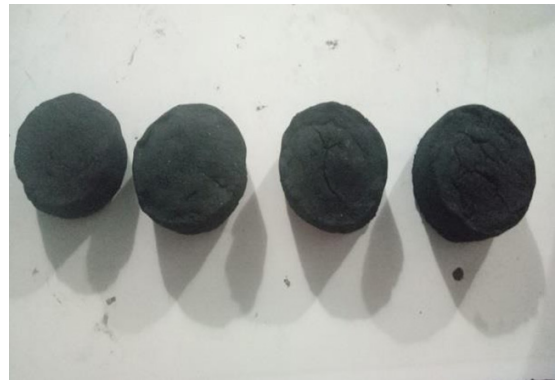

Gambar 1. Alat pengepres. 
dengan ukuran partikel 80 mesh dan yang terbesar pada ukuran partikel 40 mesh sebesar $15 \pm 0,51 \%$. Meskipun kadar zat menguap pada 40 mesh tinggi tetapi masih memenuhi standar SNI. Adanya asap timbul yang banyak merupakan suatu indikasi kandungan zat menguap yang tinggi ketika briket dibakar hal ini disebabkan oleh adanya reaksi karbon monoksida (Pane et al., 2015). Tingginya kadar zat menguap suatu briket dipengaruhi oleh panjang ikatan rantai atom suatu senyawa hidrokarbon yang merupakan bahan anorganik yang dapat meningkatkan kadar zat menguap, sehingga pembakaran terjadi begitu cepat (Himawanto, 2005; Sawir, 2016).

\section{Kadar Karbon Terikat}

Kadar karbon terikat merupakan parameter

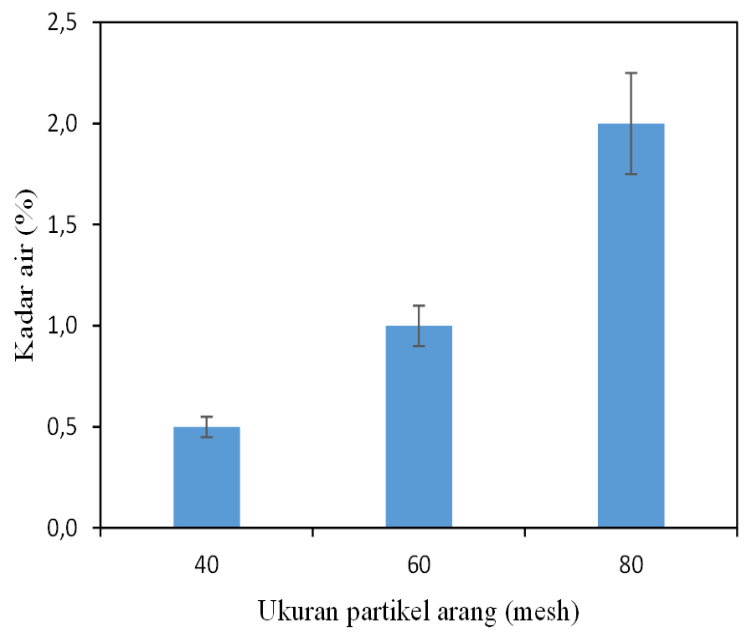

Gambar 3. Rerata kadar air (\%) berdasarkan ukuran partikel (mesh).

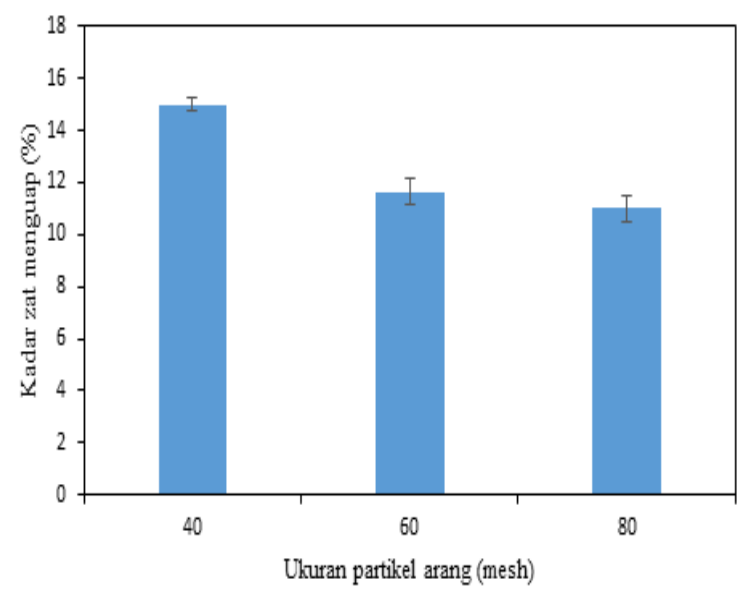

Gambar 5. Rerata kadar zat menguap (\%) berdasarkan ukuran partikel (mesh). biomassa yang dapat terbakar dalam bahan bakar padat setelah pengusiran bahan volatil. Kualitas briket arang yang baik yang memiliki nilai karbon tetap tinggi (Kongprasert et al., 2019). Kadar karbon terikat yang didapatkan berdasarkan uji analisa menunjukkan bahwa kadar karbon terikat menurun dengan ukuran partikel arang besar. Pada Gambar 6 memperlihatkan bahwa kadar karbon terikat terendah pada 80 mesh diperoleh $80,04 \pm 0,53 \%$ dan tertinggi sebesar $82,5 \pm 0,32 \%$ untuk 40 mesh. Kadar karbon terikat yang tinggi menunjukkan bahwa arang tersebut adalah arang yang baik, hal ini tergantung dari bahan baku arang (Kahariayadi et al., 2015). Berdasarkan SNI Briket 01-6235-2000, kadar karbon terikat yang harus dimiliki briket adalah minimum $\leq 77 \%$, hasil briket tutup botol sudah memenuhi.

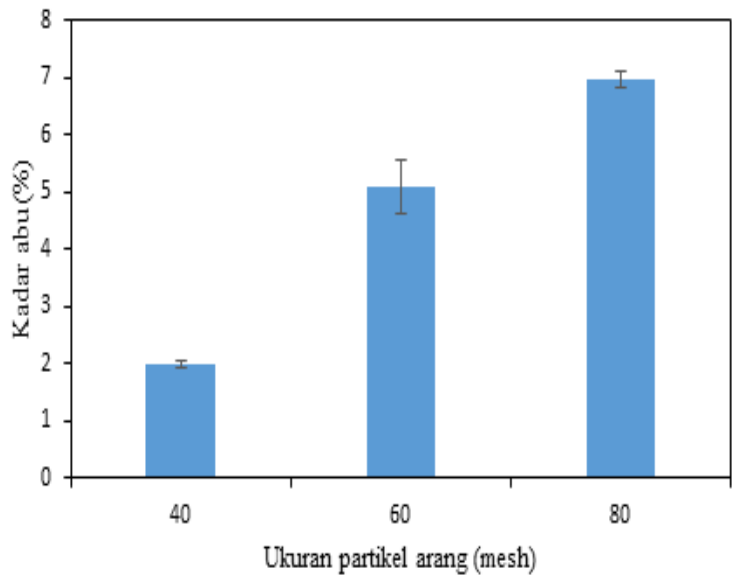

Gambar 4. Rerata kadar abu (\%) berdasarkan ukuran partikel (mesh).

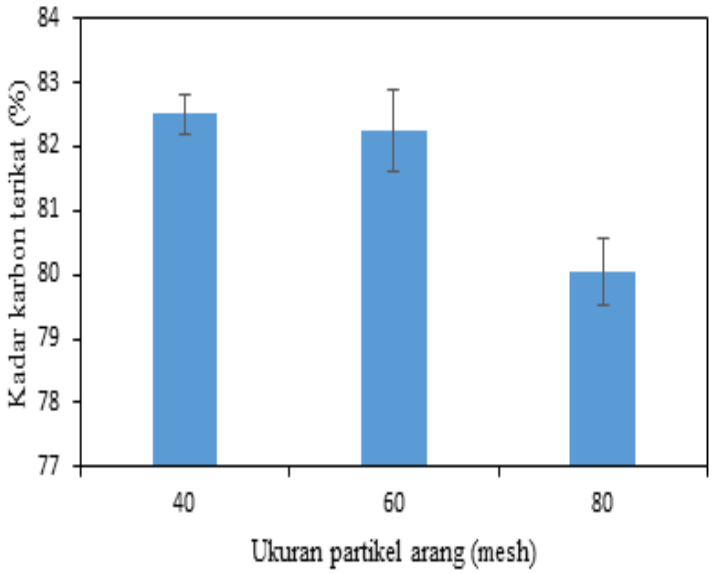

Gambar 6. Rerata kadar karbon terikat (\%) berdasarkan ukuran partikel (mesh). 


\section{Nilai Kalor}

Hasil nilai kalor yang dianalisa pada kondisi ukuran partikel arang 40 mesh, pertimbangannya melihat kadar air dan kadar abu ini memiliki hubungan semakin tinggi kadar air dan kadar abu dapat menurunkan nilai kalor. Berdasarkan hasil analisanya kadar air dan abu yang terbaik pada 40 mesh didapatkan nilai kalor sebesar 9982,779 \pm $240,017 \mathrm{kal} / \mathrm{gram}$. Sedangkan hal ini menunjukkan bahwa nilai kalor yang diperoleh lebih tinggi dari SNI Briket 01-6235-2000, yaitu $5000 \mathrm{kal} /$ gram. Nilai kalor tinggi pada briket ini disebabkan oleh kandungan material di dalam plastik yaitu rantai karbon sehingga mudah terbakar (Ruslinda et al., 2017). Plastik merupakan polimer, sehingga dapat berpengaruh pada nilai kalor bahan bakar briket (Bhoumick et al., 2016) dan plastik memiliki nilai kalor yang tinggi (Riyadi et al., 2016).

\section{KESIMPULAN}

Ukuran partikel arang dapat memberikan pengaruh terhadap kualitas briket tutup botol plastik yang dihasilkan. Berdasarkan analisa proksimat disimpulkan bahwa briket tutup botol terbaik pada kondisi ukuran partikel arang 40 mesh, dengan kadar air $0,5 \pm 0,05 \%$, kadar abu $2 \pm 0,25 \%$, kadar zat menguap $15 \pm 0,51 \%$, kadar karbon terikat $82,5 \pm 0,32 \%$, dan nilai kalor sebesar $9982,779 \pm 240,017 \mathrm{kal} / \mathrm{gram}$.

\section{DAFTAR PUSTAKA}

Asip, F., Anggun, T., \& Nurzeni, F. (2014). Pembuatan briket dari campuran limbah plastik LDPE, tempurung kelapa dan cangkang sawit. Jurnal Teknik Kimia, 20(2), 45-54.

Bhattarai, P., Sapkota, R., \& Ghimire, R. M. (2016). Effects of binder and charcoal particle size on the physical and thermal properties of beehive briquettes. Proceedings of IOE Graduate Conference, 57-63.

Bhoumick, M. C., Sarker, N. C., Hasan, M. M., \& Roy, B. K. (2016). Conversion of waste plastic into solid briquette in combination with biomass: Bangladesh perspective. International Advanced Research Journal in Science, Engineering and Technology, 3(3), 142-146. https://doi. org/10.17148/iarjset.2016.3332

Faruq, A. A. (2019). Pengaruh ukuran partikel dan temperatur furnace tanah gambut terhadap kualitas briket dari eceng gondok (Eichhornia crassipes) dan tanah gambut (Skripsi). Universitas Muhammadiyah Surakarta, Indonesia.

Gao, F. (2010). Pyrolysis of waste plastics into fuels (Thesis). University of Canterbury, New Zealand.
Hamzah, M. (2019). Sampah plastik menjadi briket sebagai bahan bakar alternatif dengan penambahan paper waste. ALKIMIA: Jurnal Ilmu Kimia dan Terapan, 3(1), 20-25. https://doi.org/10.19109/ alkimia.v3i1.3139

Hapsari, D. S. A., \& Herumurti, W. (2017). Laju timbulan dan komposisi sampah rumah tangga di Kecamatan Sukolilo Surabaya. Jurnal Teknik ITS, 6(2), C421-C424. https://doi.org/10.12962/ j23373539.v6i2.24623

Himawanto, D. A. (2015). Pengaruh temperatur karbonasi terhadap karakteristik pembakaran briket sampah kota. Media Mesin: Majalah Teknik Mesin, 6(2), 84-91. https://doi.org/10.23917/ $\underline{\text { mesin.v6i2.2893 }}$

Iskandar, N., Nugroho, S., \& Feliyana, M. F. (2019). Uji kualitas produk briket arang tempurung kelapa berdasarkan standar mutu SNI. Majalah Ilmiah Momentum, 15(2), 103-108. https://doi. org/10.36499/jim.v15i2.3073

Kahariayadi, A., Setyawati, D., Nurhaida, Diba, F., \& Roslinda, E. (2015). Kualitas arang briket berdasarkan persentase arang batang kelapa sawit (Elaeis guineensis jacq) dan arang kayu laban (Vitex pubescens vahl). Hutan Lestari, 3(4), 561568. https://doi.org/10.26418/jhl.v3i4.13182

Karim, M. A., Ariyanto, E., \& Firmansyah, A. (2014). Biobriket enceng gondok (Eichhornia crassipes) sebagai bahan bakar energi terbarukan. Reaktor, 15(1), 59-63. https://doi.org/10.14710/ reaktor.15.1.59-63

Kongprasert, N., Wangphanich, P., \& Jutilarptavorn, A. (2019). Charcoal briquettes from madan wood waste as an alternative energy in Thailand. Procedia Manufacturing, 30, 128-135. https:// doi.org/10.1016/j.promfg.2019.02.019

Naryono, E., Prayito, P., \& Santosa, S. (2019). Pembuatan briket campuran sampah organik sisa makanan dan sampah plastik sebagai binder untuk bahan bakar padat. Prosiding Seminar Nasional Rekayasa Proses Industri Kimia, 3(1), 7-9.

Pane, J. P., Junary, E., \& Herlina, N. (2015). Pengaruh konsentrasi perekat tepung tapioka dan penambahan kapur dalam pembuatan briket arang berbahan baku pelepah aren (Arenga pinnata). Jurnal Teknik Kimia USU, 4(2), 32-38. https:// doi.org/10.32734/jtk.v4i2.1468

Pek, W. K., \& Ghosh, U. K. (2015). Effect of binary mixture of waste plastics on the thermal behavior of pyrolysis process. Environmental Progress \& Sustainable Energy, 34(4), 1113-1119. https:// doi.org/10.1002/ep.12087

Prayitno, A., Hantarum, \& Sudarno. (2018). Pengaruh variasi ukuran partikel briket terhadap kerapatan, kadar air, dan laju pembakaran pada briket kayu sengon. Prosiding Seminar Nasional Sains dan Teknologi Terapan, 541-546. 
Purwanto, J., \& Sofyan, S. (2014). Pengaruh suhu dan waktu pengarangan terhadap kualitas briket arang dari limbah tempurung kelapa sawit. Jurnal Litbang Industri, 4(1), 29-38. https://doi. org/10.24960/jli.v4i1.638.29-38

Riyadi, Dwiyati, S. T., Kholil, A., \& Ilahi, A. (2016). Charcoal briquettes characteristics of HDPE mixed with water hyacinth, coconut shell, and bagasse. International Journal of Energy Engineering, 6(3), 43-48.

Ruslinda, Y., Husna, F., \& Nabila, A. (2017). Karakteristik briket dari komposit sampah buah, sampah plastik high density polyethylene (HDPE) dan tempurung kelapa sebagai bahan bakar alternatif di rumah tangga. Jurnal Presipitasi : Media Komunikasi Dan Pengembangan Teknik Lingkungan, 14(1), 5-14. https://doi. org/10.14710/presipitasi.v14i1.5-14

Sahwan, F. L., Martono, D. H., Wahyono, S., \& Wisoyodharmo, L. A. (2005). Sistem pengelolaan limbah plastik di Indonesia. Jurnal Teknologi Lingkungan, 6(1), 311-318.

Sarker, M., Rashid, M. M., \& Molla, M. (2011). New alternative vehicle hydrocarbon liquid fuels from municipal solid waste plastics. Journal of Fundamentals of Renewable Energy and Applications, 1, 1-9.

Sawir, H. (2016). Pemanfaatan sampah plastik menjadi briket sebagai bahan bakar alternatif dalam kiln di pabrik PT Semen Padang. Jurnal Sains dan Teknologi: Jurnal Keilmuan dan Aplikasi Teknologi Industri, 16(1), 62-69. https://doi. org/10.36275/stsp.v16i1.56

Septhiani, S., \& Septiani, E. (2015). Peningkatan mutu briket dari sampah organik dengan penambahan minyak jelantah dan plastik high density polyethylene (HDPE). Jurnal Kimia Valensi, 1(2), 91-96. https://doi.org/10.15408/jkv.v0i0.3567

Siddiqui, M. N., \& Redhwi, H. H. (2009). Pyrolysis of mixed plastics for the recovery of useful products. Fuel Processing Technology, 90(4), 545-552. https://doi.org/10.1016/j.fuproc.2009.01.003

Suwinarti, W., Amirta, R., \& Yuliansyah. (2018). Production of high-calorie energy briquettes from bark waste, plastic and oil. IOP Conference Series: Earth and Environmental Science, 144, 012034. https://doi.org/10.1088/1755-1315/144/1/012034

Tuffi, R., D’Abramo, S., Cafiero, L. M., Trinca, E., \& Ciprioti, S. V. (2018). Thermal behavior and pyrolytic degradation kinetics of polymeric mixtures from waste packaging plastics. Express Polymer Letters, 12(1), 82-99. https://doi. org/10.3144/expresspolymlett.2018.7

Yuliza, N., Nazir, N., \& Djalal, M. (2013). Pengaruh komposisi arang sekam padi dan arang kulit biji jarak pagar terhadap mutu briket arang. Jurnal Litbang Industri, 3(1), 21-30. https:// doi. org/10.24960/jli.v3i1.617.21-30 
